\title{
A Parallel Corpus-based Study of Interpersonal Metaphors in Hong Lou Meng and Their Translations*
}

\author{
Zhangjun Lian \\ School of Foreign Languages, Southwest University, Chongqing, China
}

\begin{abstract}
Hong Lou Meng portrays unforgettable characters by various usages of grammatical metaphors in characters' utterances. As the founder of systemic-functional linguistics, Halliday claims that the grammatical metaphors exert great impact on the conveyance of meaning in text. This study sets out to compare and contrast the interpersonal metaphors and their English translations in Chinese-English parallel corpus of Hong Lou Meng from the perspectives of mood metaphor and modality metaphor based on the theory of interpersonal metaphor in systemic functional linguistics. Through qualitative analysis of these metaphors, the difference between Chinese and English interpersonal metaphors in depicting characters and the translation style in each version of Hong Lou Meng are revealed. Then readers can have a better understanding of the characters' attitude, opinions and their interpersonal relationship in Chinese and English Hong Lou Meng.
\end{abstract}

Index Terms-interpersonal metaphors, Hong Lou Meng, grammatical metaphor, mood metaphor, modality metaphor

\section{INTRODUCTION}

Hong Lou Meng or A Dream of Red Mansions is not only a great Chinese novel but also a gem of world literature. Hong Lou Meng portrays unforgettable characters by various usages of grammatical metaphors in characters' utterances $(\mathrm{Li}, 2012)$. Systemic functional linguists claims that the grammatical metaphors exert great impact on the conveyance of meaning in text.

As the founder of systemic-functional linguistics, Halliday claims that grammatical metaphor refers to a metaphorical expression of a meaning through a lexico-grammatical form and it describes the incongruity of meaning and form at the grammatical level (Halliday \& Matthiessen, 1999; Halliday \& Matthiessen, 2008). Interpersonal grammatical metaphor and ideational grammatical metaphor are two main categories in grammatical metaphor. Interpersonal metaphor is the incongruent expression of the realization of interpersonal functions. Therefore, the interpersonal metaphors in original Chinese Hong Lou Meng have great impact on the conveyance of interpersonal meaning in source text. The key of translating these interpersonal metaphors is to functionally and adequately render the interpersonal functions connoted in original Chinese interpersonal metaphors.

Based on the theory of interpersonal metaphor in systemic functional linguistics, this study sets out to compare and contrast the interpersonal metaphors and their English translations in Chinese-English parallel corpus of Hong Lou Meng from the perspectives of mood metaphor and modality metaphor. Then the study intends to summarize the translation style in each English version of Hong Lou Meng. The corpus consists of the 120-chapter Chinese texts and its three representative English versions. The three best-known English versions chosen are The Story of the Stone (1973-86) by David Hawkes and John Minford (hereinafter referred to as Hawkes), Hong Lou Meng (1892-93) by Bencraft Joly (hereinafter referred to as Joly) and A Dream of Red Mansions (2003) by Yang Xianyi and Gladys Yang (hereinafter referred to as the Yangs).

\section{THEORETICL FRAMEWORK}

In Systemic Functional Linguistics, Halliday (1978) claims that language not only represents reality referentially through its words and structures but also represents reality metaphorically through its own internal and external form.

Grammatical metaphors are classified into interpersonal grammatical metaphor and ideational grammatical metaphor, related to interpersonal function and ideational function in language respectively.

Interpersonal grammatical metaphor is embodied on system of modality and system of mood. Therefore, it can be further classified into two kinds according to the semantic function: modality metaphor and mood metaphor. Modality refers to "a mood system in which a language user can intrude on his/her message, expressing attitudes and judgment of various kinds" (Suzanne, 1994, p. 179). As regards metaphor of modality, Halliday claims that "the explicitly subjective and explicitly objective forms of modality are all strictly speaking metaphorical, since all of them represent the

\footnotetext{
* This paper is supported by the Fundamental Research Funds for the Central Universities (Project No. CQDXWL-2013-043).
} 
modality as being substantive proposition" (Halliday, 1994, p. 362). Metaphors of modality can also be realized through expression of nominalization. Thompson claims that nominalization is "not one but two steps away from the most congruent wording" (Thompson, 2008, p. 234). Mood is "the system for symbolic exchange of commodities between speaker and listeners" (Fan, 2001, p. 110). Mood expresses the speech functions. Metaphors of mood embody compound of speech function. In the metaphorical realization of mood, "the meaning comes from the combination of both form and function" (Thompson, 2008, p. 231). The metaphorical realization of speech functions makes it possible to expand the realization of speech functions.

\section{Discussion of INTERPERSONAL Metaphors in Hong Lou MENG AND THEIR ENGLish Translations}

\section{A. Discussion of Mood Metaphors in Hong Lou Meng and Their English Translations}

In Halliday's view, mood can be classified into indicative and imperative mood, the indicative mood can further be divided into declarative and interrogative. Mood performs the basic speech functions: statement, command, offer and question. Metaphor of mood refers to the remapping between moods and speech functions which are associated with the exchange system of language. Some functions are metaphorically realized by different mood. The complicated interpersonal relationship in Hong Lou Meng is constructed through mood system in language. There are various ways to translate the original interpersonal meaning through the mood system. The difference between Chinese and English mood metaphors in depicting characters and the translation style in each version of Hong Lou Meng is illustrated in the following two examples.

(1) HLM: [宝玉]说道: “你又做什么跑来! 虽说太阳落下去, 那地上的馀热未散, 走两趟又要受了暑。我虽 然捱了打, 并不觉疼痛。我这个样儿, 只装出来哄他们, 好在外头布散与老爷听, 其实是假的。你不可认 真。”此时林黛玉虽不是嚎啕大哭, 然越是这等无声之泣, 气噎喉堵, 更觉得利害。听了宝玉这番话, 心中虽 然有万句言语, 只是不能说得, 半日, 方怞怞噎噎的说道: “你从此可都改了罢! ”宝玉听说, 便长叹一声, 道: “你放心，别说这样话。就便为这些人死了，也是情愿的！”(Cao \& Gao, 2000, p. 450-451)

Hawkes: [Baoyu] said. "Now what have you come for?" he said. "The sun's not long set and the ground must still be very hot underfoot. You could still get a heat-stroke at this time of day, and that would he a fine how do you do. Actually, in spite of the beating, I do n't feel very much pain. This fuss I make is put on to fool the others. I'm hoping they'll spread the word around outside how badly I've been hurt, so that Father gets to hear of it. It's all shamming, really. You must n't be taken in by it." Dai-yu's sobbing had by this time ceased to be audible; but somehow her strangled, silent weeping was infinitely more pathetic than the most clamorous grief. At that moment volumes would have been inadequate to contain the things she wanted to say to him; yet all she could get out, after struggling for some time with her choking sobs, was: "I suppose you'll change now." Bao-yu gave a long sigh. "Do n't worry, I shall not change. People like that are worth dying for. I would n't change if he killed me." (Hawkes, 1973, p. 159)

Joly: [Baoyu] asked. "What do you once more come here for?" "The sun, it is true, has set; but the heat remaining on the ground has n't yet gone, so you may, by coming over, get another sunstroke. Of course, I've had a thrashing but I do n't feel any pains or aches. If I behave in this fashion, it's all put on to work upon their credulity, so that they may go and spread the reports outside in such a way as to reach my father's ear. Really it's all sham; so you must n't treat it as a fact!" If I behave in this fashion, it's all put on to work upon their credulity, so that they may go and spread the reports outside in such a way as to reach my father's ear. Really it's all sham; so you must n't treat it as a fact!" Though Lin Tai-yu was not giving way at the time to any wails or loud sobs, yet the more she indulged in those suppressed plaints of hers, the worse she felt her breath get choked and her throat obstructed; so that when Pao-yu's assurances fell on her ear, she could not express a single sentiment, though she treasured thousands in her mind. It was only after a long pause that she at last could observe, with agitated voice: Though Lin Tai-yu was not giving way at the time to any wails or loud sobs, yet the more she indulged in those suppressed plaints of hers, the worse she felt her breath get choked and her throat obstructed; so that when Pao-yu's assurances fell on her ear, she could not express a single sentiment, though she treasured thousands in her mind. It was only after a long pause that she at last could observe, with agitated voice: "You must after this turn over a new leaf." At these words, Pao-yu heaved a deep sigh. He urged. "Compose your mind, "Do n't speak to me like this; for I am quite prepared to even lay down my life for all those persons!" (Joly, 1892, p. 551)

The Yangs: [Baoyu] said. "You should n't have come," "Though the sun's set, the ground is still hot. Walking here and back may make you unwell again. I'm not in any pain after my beating, just putting on an act to fool them so that word of it will get out to my father. I'm shamming actually. Do n't you worry about me. Daiyu was not crying aloud. She swallowed her tears in silence till she felt as if she would choke. She had a thousand replies to make to Baoyu, but not one word could she utter. At long last she sobbed: "Never do such things again." replied Baoyu with a long sigh. "Do n't you worry," "Please do n't talk this way. I would die happily for people like them, and I'm still alive." (The Yangs, 2003, p. 669)

The example (1) is extracted from the scenario in which Baoyu takes a beating from his father Jia Zheng. In this scenario there are four interlocutors: Baoyu, Xiren, Baochai and Daiyu. The three people respectively visit Baoyu who takes a beating from Jia Zheng. Through the analysis of the mood metaphor in the scenario, the relationship between Baoyu and Daiyu is vividly revealed. The main reason of beating Baoyu is his unwillingness to follow the official 
career set by Jia Zheng. Jia Zheng is a disciplinarian and Confucian scholar; therefore he imposes strict rules on his son. The unwillingness is contrary to Jia Zheng's expectations of restructuring family business. The confrontation reflects the sharp ideological conflicts between father and son. Jia Zheng almost put his son to death, such behavior conveys the conservative orthodoxy's extreme hatred of rebellious consciousness (Xu, 2010). But Baoyu does not give up his pursuit of ideals and freedom. Therefore Baoyu said: “就便为这些人死了, 也是情愿的。(I am quite prepared to even lay down my life for all those persons!)".

Seeing Daiyu's two eyes so swollen, as to look as big as peaches, and her face glistening all over with tears, Baoyu firstly heaves a sigh with a shout of “Ai-yo", and then reproaches Daiyu with the interrogative clause “你又做什么来 了! ”. The surface meaning of the clause expresses Baoyu's reproach to Daiyu's coming, but the term of address “你” reveals the intimate relationship between Baoyu and Daiyu.

Mood metaphor is the inconsistency between speech roles and mood choices. In the Chinese text, the congruent expression of command “你不应该来这里” is expressed with an interrogative metaphorical clause “你又做什么来 了! ”. In the Yangs' version, the congruent form of imperative clause "You should n't have come" is used to translate the command, the mood metaphor is not employed. Then the intimate relationship between Baoyu and Daiyu is ignored by the imperative clause. The Yangs' version ignores the mood metaphor in the original Chinese clause. While in both Hawkes and Joly's versions, metaphorical forms of interrogative clause are used to reveal the intimate relationship. The surface meaning of interrogative clause is to reproach Daiyu's coming, but the intended meaning of the clause is to display Baoyu's love and care. The sun is not long set, but the heat remaining on the ground has not yet gone. Walking here and back may make Daiyu unwell again. Through these utterances, Baoyu is concerned with Daiyu's physical condition. Moreover, Baoyu's pretence of feeling any pains is to fool his father. From the perspective of psychological emotion, Baoyu is concerned with Daiyu's spiritual condition. Baoyu moves his Cousin Daiyu by affection and Daiyu loves Baoyu with extreme affection (Chang, 1993).

In Chinese Hong Lou Meng, the most frequently used modal particles are “呢”, “么”, “罢”, etc. and their functions are to express the different mood of the clause. In Chinese language, the realization of mood metaphor is realized through modal particles (Yang, 2009, p. 26). In the Chinese example, the realization of mood metaphor “你从此可都改 了罢! ” is dependent on the modal particle “罢” at the end of the imperative clause. The modal particle “罢” transforms the mood of imperative into the mood of consultation. The meaning of modal particle "的” equals to "it is a fact that...", expressing the modal meaning of high value probability. The modal particle “的” in the structure “是...的” conveys Baoyu's attitude of high value probability which is achieved through the modal particle "的" at the end of the clause.

In the Yangs and Joy's versions, no mood metaphor is employed to achieve the equivalence between the target clause and the source one which contains the metaphorical form. Imperative clauses are used to display Daiyu's reaction to Baoyu's beating. In Joly's version, high value modal verb "must" carries high obligation. Such usages contain the compelling tone. Consequently the intimate relationship between Baoyu and Daiyu is ignored. While in Hawkes' version, the usage of "I suppose" euphemistically implies Daiyu's request, displaying their intimate relationship. The address “你” in Daiyu's unique utterance echoes with Baoyu's usage of the address term. Among the three English versions, both Hawkes' and Joly's version use the address term “you”. The median value modal verb “可” means “可 以”, “应当”, connoting the tone of consultation. In Hawkes” version, the median value modal verb "will” achieves the equivalence between the source clause and the target one, indicating Daiyu's understanding and consideration for Baoyu's feelings. While in Joly's version the high value modal verb "must" connotes the compelling meaning.

(2) HLM: 凤姐凑趣笑道: “一个老祖宗给孩子们作生日，不拘怎样，谁还敢争，又办什么酒戏。既高兴要热 闹, 就说不得自己花上几两。巴巴的找出这霉烂的二十两银子来作东道, 这意思还叫我赔上。果然拿不出来也 罢了, 金的, 银的, 圆的, 扁的, 压塌了箱子底, 只是勒掯我们。举眼看看, 谁不是儿女? 难道将来只有宝兄 弟顶了你老人家上五台山不成? 那些梯已只留与他, 我们如今虽不配使, 也别苦了我们。这个够酒的? 够戏 的?”说的满屋里都笑起来。(Cao \& Gao, 2000, p. 292)

Hawkes: Xi-feng made this the occasion for a little raillery. She said, "If the old lady says she wants her grandchild's birthday celebrated, then celebrated it must be, and we must all jump to it without arguing! But if she's going to start asking for plays as well, all I can say to that is that if she's in the mood for a bit of fun, I'm afraid she's going to have to pay for it. She's going to have to cough up something out of those private savings of hers she's been hoarding all these years-not wait until the last minute and then fish out a measly little twenty taels to pay for the party: that's just another way of telling us we've got to pay for it ourselves. I mean, if you were really hard up, it would be another matter: but you've got boxes and boxes of boodle-the bottoms are dropping out of them, they're so fall! It's pure meanness, that's what it is! You've got other grandchildren too, do n't forget! You forget, Grannie, when you go to heaven young Bao-yu wo n't be the only one who'll walk ahead of the hearse. You do n't have to leave everything to him. The rest of us may not be much use, but you must n't be too hard on us. Twenty taels! Do you really think that's enough to pay for a party and plays? Twenty taels! Do you really think that's enough to pay for a party and plays? At this point the entire company burst into laughter, which Grandmother Jia joined in herself." she said. (Hawkes, 1973, p. 432) 
Joly: Lady Feng thereupon smiled and ventured, with a view to enhancing her good cheer, "A venerable senior like yourself, is at liberty to celebrate the birthday of a child in any way agreeable to you, without any one presuming to raise any objection; but what's the use again of giving a banquet? But since it be your good pleasure and your purpose to have it celebrated with éclat, you could, needless to say, your own self have spent several taels from the private funds in that old treasury of yours! But you now produce those twenty taels, spoiled by damp and mould, to play the hostess with, with the view indeed of compelling us to supply what's wanted! But had n't you really been able to contribute any more, no one would have a word to say; but the gold and silver, round as well as flat, have with their heavy weight pressed down the bottom of the box! and your sole object is to harass us and to extort from us. But raise your eyes and look about you; who is n't your venerable ladyship's son and daughter? and is it likely, pray, that in the future there will only be cousin Pao-yu to carry you, our old lady, on his head, up the Wu T'ai Shan? You may keep all these things for him alone! but though we may n't at present, deserve that anything should be spent upon us, you should n't go so far as to place us in any perplexities (by compelling us to subscribe). And is this now enough for wines, and enough for the theatricals?" (Joly, 1892, p. 348)

The Yangs: Xifeng teased, "When an Old Ancestress wants to celebrate some grandchild's birthday, no matter how grandly, who are we to protest? So there's to be a feast and opera too, is there? Well, if you want it to be lively you'll have to pay for it yourself instead of trying to play host with a moldy twenty taels. I suppose you expect me to make up the rest? If you really could n't afford it, all right. But your cases are bursting with gold and silver ingots of every shape and size the bottoms of the chests are dropping out, they're so full. Yet you're still squeezing us. Look, are n't all of us your children? Is Baoyu the only one who'll carry you as an immortal on his head to Mount Wutai, that you keep everything for him? Even if the rest of us are n't good enough, do n't be so hard on us. Is this enough for a feast or theatricals?" The whole company burst out laughing. (The Yangs, 2003, p. 423-424)

Talking about the other grandchild, Wang Xifeng's utterance actually concerns about Lady Dowager in the example (2). Wang Xifeng is one of the most outstanding characters and one of the members of "the Twelve Beauties of Jin Ling" in Hong Lou Meng. She is the most powerful woman of the Jia Clan, after Grandmother Jia and Lady Wang. On the one hand, the author of HLM portrays Wang Xifeng as a clever and capable hostess with the ability of dealing with people and things well; on the other hand, she is portrayed as a greedy and arrogant master with super power in the Rong mansion ( $\mathrm{Li} \& \mathrm{Li}, 2011$ ). "Hating and cursing Xifeng, you may miss Xifeng when she is absent" (Wang, 2004, p. 152). Lady Dowager has the highest status in the Rong mansion. Lady Dowager is superordinate to Wang Xifeng.

Mood metaphor is used in the clause “难道将来只有宝兄弟顶了你老人家上五台山不成? ” (Cao \& Gao, 2000, p. 292). Through the usage of mood metaphor, Wang Xifeng pretends to complain Lady Dowager but to compliment her. In Joly's and the Yangs' versions, metaphorical clauses are used to reveal Wang Xifeng's talent and smartness on communicative skills with the aim of flattering Lady Dowager. While in Hawkes' version, the tone of compelling is imposed by the high value modal verb "won't" in imperative clause. The flatter in an insincere way can make Lady Dowager happier than a normal compliment. She exaggerates Lady Dowager's stinginess in order to delight Lady Dowager.

In different situational context, the interpersonal interaction leads to the deviation of mood choices. Therefore, mood metaphor plays a significant role in interpersonal interaction. In the Chinese text, the congruent declarative clause “举 眼看看, 我们都是儿女” is expressed with an interrogative metaphorical clause “举眼看看, 谁不是儿女? ”. Wang Xifeng and Lady Dowager share family relationship. Wang Xifeng is worldly and tactful, she is able to flatter Lady Dowager and the other powerful ladies within the family. The surface meaning of the mood metaphor clause is to reproach and query Lady Dowager about her attitude towards grandchild. But she knows that Lady Dowager enjoys having a jolly and relaxed time. A not-so-well educated upper-class woman, Wang Xifeng is also known as "Peppercorn Feng" or "Hot Pepper". Her nickname "Fiery Phoenix" reveals her spicy disposition. Therefore, her spicy disposition is embodied by her spicy temper. She is the most cynical and pungent master in the whole mansion (Chen \& Zhang, 2006). It is the language used by Wang Xifeng that makes Lady Dowager's life more fun. She is expert in flattering Lady Dowager. So Wang Xifeng blames Lady Dowager with real intension to increase the affection with Lady Dowager. In Hawkes' version, the declarative clause "You've got other grandchildren too, do n't forget!" is employed to translate the congruent form of the original clause, then the metaphorical meaning is lost and the speech function is not faithful to the original clause. While in Joly's and the Yangs' versions, interrogative clauses are used to translate the mood metaphor of the original clause, connoting the intended intension to retain and increase their intimate relationship. Then the speech function is faithful to the original text. Equivalence of translation is achieved in these two versions. Translators approximately convey the interpersonal function of the original text. Wang Xifeng's arrogance and snobbishness are vividly displayed.

“凑趣” in original text presents Wang Xifeng's speaking tone with the aim of delighting Lady Dowager. In Hawkes” and the Yangs' version, "teased" and "raillery" are used to present Wang Xifeng's tone in the translation. While in Joly's version, the word "ventured" lengths the relationship between Wang Xifeng and Lady Dowager, and violates Xifeng's original attitude.

The term of address performs the interpersonal function. The usage of the term of address reflects the status, identity of speakers and listeners. The term of address is essential mean of conveying interpersonal function of language (Hong, 2001). The term of address “老祖宗” reflects Lady Dowager's super power in the whole mansion. Wang Xifeng 
addresses Lady Dowager as “老祖宗” to show her respect towards Lady Dowager. In Joly’s version, this address is translated as "senior" which lengthens the relationship between Wang Xifeng and Lady Dowager. While "an old ancestress" in the Yangs' version is faithful to the original both in form and interpersonal function. The term of address “宝兄弟” indicate such intimate relationship. Among the English versions, the word “cousin” in Joly”s version equivalently expresses the intimate relationship. While in the other two versions, Wang Xifeng's relation to Baoyu by blood and by marriage is not displayed functionally and equivalently.

\section{B. Discussion of Modality Metaphors in Hong Lou Meng and Their English Translations}

Systemic functional linguistics claims that modality is one of the means of expressing interpersonal function of language. Modality in language displays the speakers' social status, attitudes, responsibility, commitment, etc. The complicated interpersonal relationship in Hong Lou Meng is also constructed through modality system in language. There are various ways to translate the original interpersonal meaning through the modality system. The difference between Chinese and English modality metaphors in depicting characters and the translation style in each version of Hong Lou Meng is illustrated in the following example.

(3) HLM: 黛玉叹道: “你（宝钗）素日待人，固然是极好的，然我最是个多心的人，只当你心里藏奸。从前 日你说看杂书不好, 又劝我那些好话, 竟大感激你。往日竟是我错了, 实在误到如今。细细算来, 我母亲去世 的早, 又无姊妹兄弟, 我长了今年十五岁, 竟没一个人像你前日的话教导我。怨不得云厂头说你好, 我往日见 他赞你, 我还不受用, 昨儿我亲自经过, 才知道了。比如若是你说了那个, 我再不轻放过你的, 你竟不介意, 反劝我那些话, 可知我竟自误了。”(Cao \& Gao, 2000, p. 606)

Hawkes: Dai-yu sighed again. She said, "You're such a kind person, but I've got such a suspicious nature that in the past I always suspected that your kindness was a cloak for something and rejected it. It was n't until the other day, when you told me off for reading forbidden books and offered me all that good advice, that I ever felt really grateful to you. I realized then that I had all along been wrong about you-right from the very start. I suddenly realized: I'm fifteen this year and have no brothers or sisters: ever since my mother died there has been no one-literally no one-who has ever spoken to me in that sort of way. I'm not surprised Cousin Yun speaks so highly of you. I used to hate it when I heard her praise your kindness, but since experiencing it myself, I know what she means. If it had been you who'd said those things in the drinking game, I should have been quite merciless. I should never have kept quiet about it at the time and gently remonstrated about it later, when we were alone together, as you did I knew from that that I had been wrong about you, and that you must really care for me.” (Hawkes, 1973, p. 397)

Joly: "You've certainly always treated people with extreme consideration," sighed Tai-yu, "but such a supremely suspicious person am I that I imagined that you inwardly concealed some evil design! Yet ever since the day on which you represented to me how unwholesome it was to read obscene books, and you gave me all that good advice, I've felt most grateful to you! I've hitherto, in fact, been mistaken in my opinion; and the truth of the matter is that I remained under this misconception up to the very present. But you must carefully consider that when my mother died, I had n't even any sisters or brothers; and that up to this my fifteenth year there has never been a single person to admonish me as you did the other day. Little wonder is it if that girl Yun speaks well of you! Whenever, in former days, I heard her heap praise upon you, I felt uneasy in my mind, but, after my experiences of yesterday, I see how right she was. When you, for instance, began to tell me all those things, I did n't forgive you at the time, but, without worrying yourself in the least about it you went on, contrariwise, to tender me the advice you did. This makes it evident that I have labored under a mistaken idea!" (Joly, 1892, p. 754)

The Yangs: "How good you always are to others!" Daiyu exclaimed with a sigh. "I'm so touchy that I used to suspect your motives. I really began to appreciate you that day when you warned me against indiscriminate reading and gave me such good advice. I can see now I'd misjudged you all along. My mother died early and I've no sisters or brothers so, come to think of it, in all my fifteen years no one ever advised me as you did the other day. No wonder Xiangyun speaks so highly of you. I used to be skeptical when she sang your praises, but not after my own recent experience. For instance, when you said anything I always answered back, but instead of taking offence you offered me good advice. That showed that I'd been wrong." (The Yangs, 2003, p. 912)

The example (3) is extracted from the scenario in which Xue Baochai comes to visit sick Lin Daiyu who expresses her appreciation to Xue Baochai. In the Chinese text, the clause “可知我竟自误了。” is a modality metaphor which achieves the metaphorical probability realization. "In order to state explicitly that probability is subjective, or alternatively, at the other hand, to claim explicitly that the probability is objective, the speaker construes the proposition as a projection and encodes the subjectivity (I think), or the objectivity (it is likely), in a projecting clause" (Halliday \& Matthiessen, 2008, p. 615). The way of expressing modality in the Chinese clause is explicit objectivity which emphasizes the objectivity of Lin Daiyu's judgment. Lin Daiyu is portrayed as an aloof, well-educated and beautiful character in Hong Lou Meng. She defends her characters and integrity forever (Zhang, 2009). Despite her dependency on Lady Dowager for her living, Lin Daiyu refuses to yield to the Confucian ethics. Lin Daiyu's personality is such a match with that of Jia Baoyu who is having little interest in learning the Confucian classics and enjoying reading or writing poetry with numerous female characters. Increasingly Lin Daiyu and Jia Baoyu become fond of each other. But Xue Baochai is deeply involved in Lin Daiyu and Jia Baoyu's love. Therefore Lin Daiyu and Xue Baochai are probably conceived as foils to each other. The surface meaning of the Chinese modality metaphor is to express her appreciation 
to Xue Baochai, in fact, the intended meaning is to express Lin Daiyu's jealousy because Xue Baochai is liked by all the mistresses and servants of the whole mansion. Though modality metaphors are used to translate the original metaphorical clause in the three English versions, the metaphor "I knew from that" in Hawkes' version is explicit subjectivity which denotes a psychological process. The process connotes the subjectivity which violates with the objective Chinese clause. The Yangs' and Joly's versions are faithful to the original Chinese clause both in form and interpersonal function. "That showed" and "This makes it evident" in the clauses make Lin Daiyu's judgment objective, and the explicit objectivity reveals her jealousy.

\section{CONCLUSION}

Based on the theory of interpersonal metaphor in systemic functional linguistics, this study sets out to compare and contrast the interpersonal metaphors and their English translations in Chinese-English parallel corpus of Hong Lou Meng from the perspectives of mood metaphor and modality metaphor.

The number of interpersonal metaphors in Chinese Hong Lou Meng is greater than that in English versions of Hong Lou Meng. There are various ways of realizing the interpersonal function by mood system in Chinese Hong Lou Meng. Modal particles, terms of address, stereotyped structures, all these devices help the realization of interpersonal function by mood metaphor. In Hawkes' and Joly's versions, the interpersonal functions connoted in original Chinese are functionally and adequately rendered because of the frequently used mood metaphors. While the seldom used mood metaphor in the Yangs' version causes the loss of the interpersonal function of the original clause in Hong Lou Meng. Though the modality metaphors are used to translate the original Chinese metaphorical clause in the three English versions, the Yangs' and Joly's versions are faithful to the original Chinese clause both in form and interpersonal function. The Hawkes' version is faithful to the original clause only in form, losing the interpersonal function of the original clause in Hong Lou Meng.

Through the discussion of the main means of realizing the interpersonal function by the mood and modality metaphor, the readers could not only have a comprehensive appreciation of Chinese and English interpersonal metaphors in Hong Lou Meng, but also have a better understanding of the characters' attitude, opinions and their interpersonal relationship in Chinese and English Hong Lou Meng.

\section{REFERENCES}

[1] Cao, X. Q., \& Gao, E. (2000). Hong Lou Meng. Beijing: People’s Literature Publishing House.

[2] Chang, J. N. (1993). On Expression and Understanding of Verbal Communication. Applied Linguistics, 3, 86-92.

[3] Chen, D. Y., \& Zhang, R. E. (2006). Translation of Wang Xifeng's personalized utterances. Foreign Language Education, 5, 81-84.

[4] Chen. J. (2011). An Analysis of Entanglement love between Baoyu and Daiyu from three conversations. Yangtze River Academic, 1, 69-78.

[5] Fan, W. F. (2001). A Research on Grammatical Metaphor. Beijing: Foreign Language Teaching and Research Press.

[6] Halliday, M. A. K. (1978). Language as Social Semiotic: the Social Interpretation of Language and Meaning. London: Edward Arnold.

[7] Halliday, M. A. K. (1994). An Introduction to Functional Grammar. London: Edward Arnold.

[8] Halliday, M. A. K., \& Matthiessen, C. (1999). Construing Experience through Meaning: A Language-based Approach to Cognition. London \& New York: Continnum.

[9] Halliday, M. A. K., \& Matthiessen, C. (2008). An Introduction to Functional Grammar (3rd ed.). Beijing: Foreign Language Teaching and Research Press.

[10] Hawkes, D., \& Minford, J. (1973-1986). The Story of the Stone, Vol. 1-5. London: Penguin Books.

[11] Hong, T. (2001). The English translation of Hong Lou Meng and Eastern and Western Culture and Language. Journal of Hong Lou Meng, 4, 291-306.

[12] Joly, H. B. (1892-1893). Hung Lou Meng, or The Dream of the Red Chamber, a Chinese Novel, Vol. 1-2. Hong Kong: Kelly and Walsh.

[13] Li, X. Y. (2012). Construction of Interpersonal Meaning in the Translation of Wang Xifeng's Speech. M. A. Thesis, Xi'an: Shaanxi Normal University.

[14] Li, X. F., \& Li, M. (2011). On Wang Xifeng's image. Journal of Hong Lou Meng, 4, 1-29.

[15] Suzanne, E. (1994). An Introduction to Systemic Functional Linguistics. London: Pinter Publishers.

[16] Thomspon, G. (2008). Introducing Functional Grammar ( $2^{\text {nd }}$ ed.). London: Hodder Arnold/Beijing: Foreign Language Teaching and Research Press.

[17] Wang, K. L. (2004). On Characters in Hong Lou Meng. Beijing: Beijing Press.

[18] Xu, J. Y. (2010). Pragmatic Analysis of Xue Baochai's and Lin Daiyu's Utterances in A Dream of Red Mansions. M. A. Thesis, Shanxi: Shanxi Normal University.

[19] Yang, C. Y. (2009). The Interpersonal Meaning of Chinese Modal Particles. Foreign Language and Literature, 6, $26-32$.

[20] Yang, X. Y., \& Yang, G. (2003). A Dream of Red Mansions. Beijing: Foreign Languages Press.

[21] Zhang, L. L. (2009). On Lin Daiyu's image. Journal of Hong Lou Meng, 1, 11-33. 
Zhangjun Lian was born in Shanxi, China in 1981. He received his M.A. degree in English language and literature from Yanshan University, China in 2007.

$\mathrm{He}$ is currently a Ph.D. candidate in the School of Foreign Languages, Southwest University, Chongqing, China. His research interests include functional linguistics, translation studies and corpus linguistics. 